\title{
THE SOUTH EAST EUROPEAN (SEE) - PTSD STUDY
}

\author{
Jürgen Deckert \\ Department of Psychiatry, Psychosomatics and Psychotherapy, Center of Mental Health, \\ University Hospital of Würzburg, Würzburg, Germany \\ $* * * * *$
}

In 2016, Psychiatria Danubina published a manuscript by A. Dzubur-Kulenovic and coauthors on the rationale, design and methods of the South East European (SEE)PTSD study. The study went back to an initiative by P. Riederer funded by the DAAD stability pact. The SEEPTSD consortium combined clinical expertise from psychiatric departments in Mostar (R. Babic, M. Pavlovic, D. Babic), Pristina (A. Goci Uka, S. Haxhibequiri, V. Haxhibequiri, B. Hoxha, G. Vyshka, F. Agani), Sarajevo (S. Kucukalic, E. Sabic Dzananovic, A. Bravo Mehmedbasic, A. Kucukalic, A. Dzubur-Kulenovic), Tuzla (N. Kravic, M. Muminovic, O. Sinanovic, E. Avdibegovic) and Zagreb (N. Jaksic, A. Cima, D. Rudan, B. Aukst Margetic, M. Jakovljevic) with genetic and epigenetic competence from the psychiatric department in Würzburg.

Between 2011 and 2016 a clinical cohort consisting of 397 patients with current or life-time PTSD and 350 ethnically, gender and age matched controls was recruited by the participating centers from South East Europe after obtaining local ethics votes (Dzubur-Kulenovic et al. 2016). In 2016 according to the a priori protocol, the promotor region of the monoamine oxidase $\mathrm{A}(M A O-A)$ gene was investigated for epigenetic methylation changes associated with post-traumatic stress disorder in Würzburg and hypermethylation found to be associated with reexperience of trauma and hyperarousal in men (Ziegler et al. 2018). Further epigenetic analyses are expected to follow, supported by the DFG funded CRC TR58 on „Fear, Anxiety and Anxiety Disorders“ (speaker C. Pape).

In 2016 in an exploratory approach, the cohort was also genotyped in Würzburg for genetic polymorphisms in 19 candidate genes selected from the literature and based on their neurobiology assumed to be relevant for mental disorders associated with trauma. Selection of the candidate genes was performed in an interactive and reciprocal process between the South East European $\mathrm{PhD}$ students on one side and the psychiatric geneticists from Würzburg on the other side. Part of this had been done during hospitations of the South East European $\mathrm{PhD}$ students in the functional genomics laboratory of Würzburg psychiatry. The candidate genes included genes of monoaminergic neurotransmission (SLC6A4, MAO-A, COMT, TPH2, SLC6A3, HTR1A, DRD2 and DRD4), genes of several other neurotransmission systems (GAD1, NPSR1,
CNR1, NPY, OXTR), genes of the HPA-axis (CRHR1, $F K B P 5)$, growth factor and immunomodulatory genes $(B D N F, I L-6)$ and other genes reported to be involved in PTSD (RORA, MBP). In 2017, results were analyzed and discussed, and in 2018, manuscripts were prepared for Psychiatria Danubina edited by M. Jakovljevic.

Besides the scientific output of the consortium with a proof-of-principle epigenetic finding on $M A O-A$ gene methylation and numerous nominally significant genetic associations in PTSD, another and maybe the most important outcome was the collaboration experience made by scientists from countries which were in a devastating war less than 20 years ago. This collaboration experience involved not only collaboration between psychiatric departments from several countries in South East Europe, but also between psychiatric departments and institutes with genetic competence in the respective countries (N. Bozina, E. Feric Bojic, D. Marjanovic) as well as Würzburg (C. Ziegler, C. Wolf, B. Warrings, K. Domschke and J. Deckert). It also allowed for an exchange of young $\mathrm{PhD}$ students from the consortium with young $\mathrm{PhD}$ students from Germany in joint meetings at Würzburg in the context of the DFG funded RTG 1253 (speaker P. Pauli). It contributed to several $\mathrm{PhD}$ theses by the participating South East European PhD students.

The SEE-PTSD consortium funded by the DAAD, thus has not only added to our insight into the molecular mechanisms of PTSD, but may also serve as a blueprint for a collaborative academic development of a new academic generation from South East Europe in a regional and European context.

\section{References}

1. Dzubur-Kulenovic A, Agani F, Avdibegovic E, Jakovljevic $M$, et al.: Molecular mechanisms of Post-traumatic stress disorder (PTSD) as a basis for indvidualized and personalized therapy: Rationale, methods and design of the South East Europe (SEE) - PTSD study. Psychiatr Danub 2016; 28:154-163

2. Ziegler C, Wolf C, Schiele MA, Feric Bojic E, et al.: Monoamine Oxidase A Gene Methylation and its Role in Posttraumatic Stress Disorder: First Evidence from the South East Europe (SEE)-PTSD Study. Int J Neuropsychopharmacol 2018; 21:423-432

\section{Correspondence:}

Professor Jürgen Deckert, $M D, P h D$

Department of Psychiatry, Psychosomatics and Psychotherapy, Center of Mental Health, University Hospital of Würzburg

Würzburg, Germany

E-mail: Deckert_J@ukw.de 